\title{
Controls on microalgal community structures in cryoconite holes upon high-Arctic glaciers, Svalbard
}

\author{
T. R. Vonnahme ${ }^{1,2, a}$, M. Devetter ${ }^{1,3}$, J. D. Žárský $\dot{y}^{1,4}$, M. Šabacká ${ }^{1,5}$, and J. Elster ${ }^{1,6}$ \\ ${ }^{1}$ Centre for Polar Ecology, Faculty of Science, University of South Bohemia, České Budějovice, Czech Republic \\ ${ }^{2}$ University of Konstanz, Constance, Germany \\ ${ }^{3}$ Biology Centre of the Academy of Science of the Czech Republic, Institute of Soil Biology, \\ České Budějovice, Czech Republic \\ ${ }^{4}$ Department of Ecology, Charles University, Prague, Czech Republic \\ ${ }^{5}$ British Antarctic Survey, Cambridge, UK \\ ${ }^{6}$ Institute of Botany, Academy of the Science of the Czech Republic, Třeboň, Czech Republic \\ a now at: Max Planck Institute for Marine Microbiology, Bremen, Germany
}

Correspondence to: J. Elster (josef.elster@ibot.cas.cz)

Received: 27 May 2015 - Published in Biogeosciences Discuss.: 29 July 2015

Revised: 8 January 2016 - Accepted: 14 January 2016 - Published: 3 February 2016

\begin{abstract}
Glaciers are known to harbor surprisingly complex ecosystems. On their surface, distinct cylindrical holes filled with meltwater and sediments are considered hot spots for microbial life. The present paper addresses possible biological interactions within the community of prokaryotic cyanobacteria and eukaryotic microalgae (microalgae) and relations to their potential grazers, such as tardigrades and rotifers, additional to their environmental controls. Svalbard glaciers with substantial allochthonous input of material from local sources reveal high microalgal densities. Small valley glaciers with high sediment coverages and high impact of birds show high biomasses and support a high biological diversity. Invertebrate grazer densities do not show any significant negative correlation with microalgal abundances but rather a positive correlation with eukaryotic microalgae. Shared environmental preferences and a positive effect of grazing are the proposed mechanisms to explain these correlations. Most microalgae found in this study form colonies ( $<10$ cells, or $>25 \mu \mathrm{m})$, which may protect them against invertebrate grazing. This finding rather indicates grazing as a positive control on eukaryotic microalgae by nutrient recycling. Density differences between the eukaryotic microalgae and prokaryotic cyanobacteria and their high distinction in redundancy (RDA) and principal component (PCA) analyses indicate that these two groups are in strong contrast. Eukaryotic microalgae occurred mainly in unstable cryoconite holes
\end{abstract}

with high sediment loads, high $\mathrm{N}: \mathrm{P}$ ratios, and a high impact of nutrient input by bird guano, as a proxy for nutrients. In these environments autochthonous nitrogen fixation appears to be negligible. Selective wind transport of Oscillatoriales via soil and dust particles is proposed to explain their dominance in cryoconites further away from the glacier margins. We propose that, for the studied glaciers, nutrient levels related to recycling of limiting nutrients are the main factor driving variation in the community structure of microalgae and grazers.

\section{Introduction}

Cryoconite holes are cylindrical cavities filled with meltwater and biological active sediments found on the surface of glaciers worldwide. Their diameter can range between a few centimeters and several meters (MacDonnell and Fitzsimons, 2008). They are mainly created by airborne sediment inputs into small depressions, which result in an increased melt rate caused by a decreased albedo (McIntyre, 1984; Fountain et al., 2004). Even though they are ice-free only during the short Arctic summer, cryoconite holes can cover a large part of the ablation zone and contribute significantly to the glacier runoff (Hodson et al., 2008). Cryoconite holes are usually open and photosynthetically active for a few months 
in summer. During this time they are highly dynamic systems with occasional stripping events during which they can be cleared and the newly distributed sediment starts forming new cryoconite holes nearby (personal observations; MacDonell and Fitzsimons, 2008). During this time several cryoconite holes are connected hydrologically. Most of the year, they are sealed with an ice lid and covered by snow, which protects them from stripping events, but which also inhibits the photosynthetic activity (J. Bartlett, personal communication, 2015). Recently reviewed studies also demonstrated that glacial ecosystems have a significant impact on the global carbon cycle (Stibal et al., 2012a). Common approaches tried to find environmental controls on the net ecosystem productivity, but the biotic controls have often been overlooked. We hypothesize that the biotic controls have similar dynamics to temperate lakes, where primary productivity is controlled not only by environmental parameters (bottom-up) but also grazing pressure (top-down) (Sterner, 1986).

Cryoconite holes represent ultraoligotrophic environments (Hodson et al., 2008) inhabited by microorganisms, which are able to cope with many environmental challenges associated with a life on the surface of glaciers. Filamentous phototrophic cyanobacteria and mostly coccal heterotrophic bacteria are shown to act as ecosystem engineers within the cryoconites, capable of forming distinct dark granules up to $3 \mathrm{~mm}$ thick in diameter (Takeuchi et al., 2001; Langford et al., 2010). These granules provide a substrate for growth of surprisingly high biomasses and diversities of bacteria, cyanobacteria, eukaryotic microalgae and protozoa (Mueller et al., 2001; Christner et al., 2003; Cameron et al., 2012). Additionally, invertebrates mainly comprised of tardigrades and rotifers have been found inhabiting cryoconite holes on glaciers worldwide (De Smet and van Rompu, 1994; Grongaard and McInnes, 1999; Säwström et al., 2002; Porazinska et al., 2004; Zawierucha et al., 2014). The species diversity of these grazing invertebrates is relatively low and relatively well known but their ecological role in the cryoconite community has not been addressed yet. It is believed that they act as top predators in a microbial food web consisting of both grazing and carnivorous species (De Smet and van Rompu, 1994).

In temperate freshwater systems grazing is known to have a substantial effect on microalgal communities (to avoid duplication of terms, "microalgae" in the text also includes Cyanobacteria, unless further specified). For example, Sterner (1986) described two effects of invertebrate grazing on microalgal communities. Firstly, selective feeding can suppress the population of the preferred food organisms. Secondly, invertebrate grazing is able to release nutrients from microalgae biomasses and enhance the growth of otherwise nutrient-limited organisms. In contrast to the crustacean dominated grazer communities in temperate ponds, preying on relatively large organisms, the cryoconite communities are known to consist of much smaller grazers, usually shorter than $200 \mu \mathrm{m}$ (personal observations). Generally, Arctic fresh- water ponds are characterized by a food web with a few trophic levels, dominated by crustacean grazers with short generation times, due to the short growing season (Rautio et al., 2011). The zoobenthos community is thought to obtain its carbon from benthic primary production and associated bacterial growth (Rautio et al., 2011). Another effect of grazing has been described by Vanormelingen et al. (2009), who observed enlarged colonies of coenobium species as possible adaptation to grazing. Larger colonies are proposed to outgrow the maximum food size of filtration feeders. Bdelloid rotifers are known as size-selective filtration feeders for small cells (Ricci and Balsamo, 2000; Devetter, 2009) and are common in cryoconite holes (Zawierucha et al., 2014). Tardigrades, another part of the grazer community in cryoconite holes, are able to prey on much larger organisms (Nelson and Marley, 2000). Ciliates in cryoconite holes can generally act as grazers on microalgae and bacteria, or as prey for larger metazoans (Sinistro et al., 2007), but Mieczan et al. (2013) found that carnivorous and bacterivorous ciliates prevail in Antarctic cryoconites. Another difference between temperate and polar food webs is the slower growth rate of herbivores compared to microalgae in cold environments, which is known to lead to a weak and delayed top-down control in habitats with low temperatures (Rose and Caron, 2007). So far, none of the mechanisms described above has been studied in cryoconite holes and the significance of trophic interactions in cryoconite holes is as yet unknown.

For the present study microalgae can be classified into four dominant groups differing in their adaptations to a life on glaciers. (i) Filamentous cyanobacteria, usually consisting of Oscillatoriales (Leptolyngbya sp. and Phormidium sp.) (Mueller et al., 2001), are capable of stabilizing the cryoconite granules, which, reversely, can protect the microalgae from physical stress (Takeuchi et al., 2001). Also, a small amount of atmospheric nitrogen can be fixed by these non-heterocystous oscillatorian cyanobacteria (Bergman et al., 1997; Telling et al., 2011). (ii) Nostocales, usually consisting of Nostoc sp. (Mueller et al., 2001), can form large colonies as protection against environmental stresses and act as storage for nutrients and carbon ( $\mathrm{Li}$ and Gao 2007). They also form heterocysts capable of efficient atmospheric nitrogen fixation (Kumar et al., 2010). (iii) Chlorophyceae, mainly consisting of Chlamydomonas nivalis (Mueller et al., 2001), are well adapted to high light intensities by the production and storage of photoprotective pigments (Bidigare et al., 1993). Furthermore, snow microalgae are known to migrate to favorable microhabitats (Kavecka, 1986). (iv) Zygnematophyceae are another group of eukaryotic microalgae capable of production and storage of photoprotective pigments in a moveable vacuole (Remias et al., 2012; Yallop et al., 2012). In summary, cyanobacteria on glaciers are well adapted to nitrogen limitations, whereas green microalgae are better adapted to high light intensities and environmental disturbances. Hence, the stability and nutrient levels should 
Table 1. Sampling and analysis design, with number of sampled cryoconite holes for different analyses. Sampled sites and their abbreviations are used throughout the paper.

\begin{tabular}{llrrr}
\hline Site & Abbreviation & $\begin{array}{r}\text { Sample } \\
\text { size }\end{array}$ & $\begin{array}{r}\text { Repeated } \\
\text { sampling } \\
(4 \times)\end{array}$ & Nutrients \\
\hline Ebbabreen & E & 6 & - & - \\
Hørbyebreen & HC & 16 & 5 & 3 \\
Nordenskiöldbreen & & & & \\
main site & NC & 10 & 5 & 4 \\
Retrettøya & NR & 6 & - & 1 \\
$\begin{array}{l}\text { Supraglacial lake } \\
\text { Plateau }\end{array}$ & NL & 6 & - & - \\
\hline
\end{tabular}

Abbreviation: abbreviation for the sampling site used in the text. Sample size: number of sampled cryoconite holes. Repeated sampling $(4 x)$ : number of cryoconite holes that were sampled four times over the season. Nutrients: number of cryoconite holes where nutrient analysis were performed.

influence the ratio of green microalgae to cyanobacteria and competition is likely to occur.

The aim of the present study was to investigate the importance of environmental controls compared to biological interactions (grazing, competition) on the microalgal community structure and to discuss possible mechanisms involved. The community structures and densities of microalgae and their possible grazers were estimated and environmental parameters were measured. Correlation analyses were then applied to assess possible controls on the microalgal community structure and their relative importance.

\section{Methods}

\subsection{Site description and sampling}

Between July and August 2014, 62 cryoconite holes on the three valley glaciers Nordenskiöldbreen, Hørbyebreen (HC), and Ebbabreen (E) (Table 1, Fig. 1) around Petuniabukta and Adolfbukta in Svalbard (76-80 $30^{\prime} \mathrm{N}$ and $\left.10-35^{\circ} \mathrm{E}\right)$ were sampled. The three glaciers were all valley glaciers. Nordenskiöldbreen was separated into four sampling sites: (1) close to the glacier margin and a bird colony on the peninsula $\mathrm{Re}$ trettøya (NR), (2) on the southern site of the glacier (NC), (3) on a central plateau (NI), and (4) on the bottom of a drained supraglacial lake (NL). On Hørbyebreen, 10 samples were taken from the central part and 6 samples in $25-100 \mathrm{~m}$ elevation intervals. On Ebbabreen, in total six samples were collected every $25-100 \mathrm{~m}$ in height. As will be described, the sites vary in some environmental factors, such as nutrient availability, stability (e.g., water depth), and isolation of the cryoconite holes. For an overview of the studied glaciers see Rachlewicz et al. (2007).

The cryoconite holes are rather unstable habitats with a life span often shorter than one summer season. The closer the cryoconite hole to the glacier margin, the shorter the life span (personal observations). Hence, the cryoconite holes on the plateau on Nordenskiöldbreen have the longest life span and the cryoconite holes near Retrettøya the shortest one. During the current study 20 cryoconite holes were monitored continuously with depth measurements and photographs. We were able to show that three cryoconite holes experienced a complete stripping event and that nine of them drained but regrew at the same place (Fig. S3 in Supplement). Cryoconite holes on the present glaciers are only open for 1 to 3 months in summer, depending on their altitude. They remain rather stable after an ice lid gets formed in autumn until the snow starts melting in late June and the first parts of the glacier clear from the snow in July (personal observations). The current study focusses on the summer months because significant photoautotrophic activity is only expected during the summer season.

On the central part of Hørbyebreen and the southern site of Nordenskiöldbreen 5 cryoconite holes were sampled four times throughout the summer season (June-August) in order to test for seasonal variations. Five additional cryoconite holes on these sites were sampled at the beginning and the end of the season to test for possible impacts of the repeated sampling (Control). From all other sites six samples were taken. The samples taken, and measurements done, are summarized in Table 1.

Cryoconite sediment was collected into a $0.5 \mathrm{~L}$ polyethylene bottle with a pooter (Southwood and Henderson, 2000). Sediments in a defined area within a $4.5 \mathrm{~cm}$ plastic ring were taken. All sampling equipment was washed with meltwater from the sampling site prior to the sampling.

\subsection{Density estimations of invertebrates and ciliates}

Densities of tardigrades, rotifers and large ciliates $(>25 \mu \mathrm{m})$ were estimated as the number of individuals per square centimeter of cryoconite sediment layer. The fresh sample was transferred into a clean $120 \mathrm{~mL}$ beaker. The sample was left for at least $30 \mathrm{~min}$ to settle and the supernatant was removed until $100 \mathrm{~mL}$ of the sludge remained. The supernatant was screened randomly for planktonic individuals, but no grazers were found. The sample was then homogenized in the laboratory by shaking and a 10-20 mL subsample was taken and transferred into a $10 \mathrm{~cm}$ petri dish with parallel lines on the bottom with a distance of $5 \mathrm{~mm}$. In this subsample, the number of five functional grazers or predators was counted (tardigrades, bdelloid rotifers (Macrotrachella sp., Adineta sp.), carnivorous monogonont rotifers (Encentrum sp.), and large ciliates) with a stereomicroscope. All samples were analyzed within $24 \mathrm{~h}$ after the sampling and stored in the dark at temperatures below $4{ }^{\circ} \mathrm{C}$. In all sampling sites, only actively moving individuals were counted as estimate for their viability. For tardigrades and rotifers, species-level identification was carried out in 1-3 random sites per glacier. The rotifers were identified using the monograph of Donner (1965). 


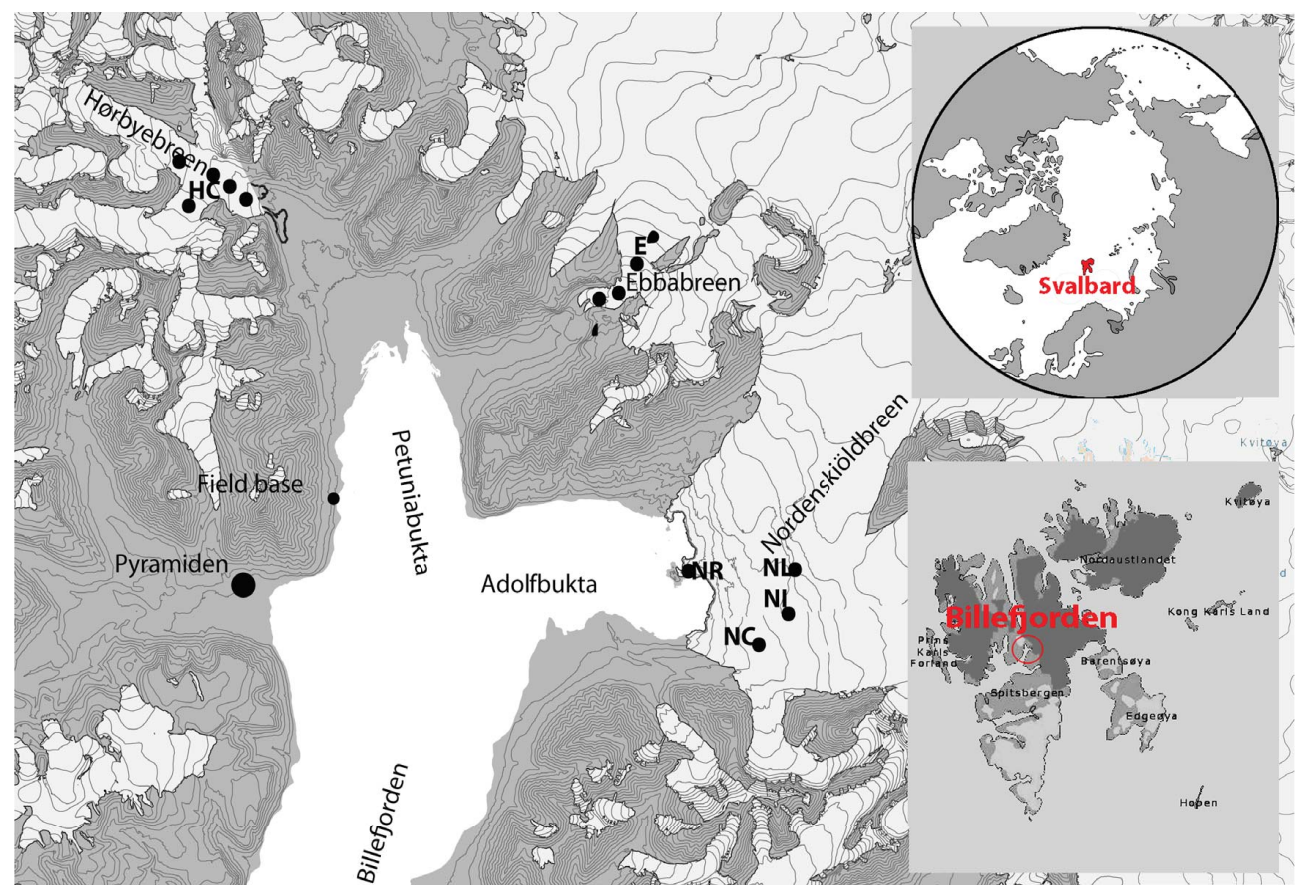

Figure 1. Sampling sites of the cryoconites. The abbreviations used are HC for Hørbyebreen, E for Ebbabreen, NC for the main site on Nordenskiöldbreen, NI for the plateau on Nordenskiöldbreen, NL for the supraglacial lake on Nordenskiöldbreen, and NR for the part of Nordenskiöldbreen next to Retrettøya. The map is modified from the geographic data of the Norwegian Polar Institute (2014).

Tardigrades were identified using the key to world tardigrade by Ramazotti and Maucci (1983) and by comparisons with other original papers (Dastych, 1988; Miller et al., 2005). The identified material is deposited in the Biology Centre of the Academy of Science of the Czech Republic, Institute of Soil Biology, in České Budějovice in the Czech Republic. All density estimations were done in the field station in Petuniabukta. The species determinations were done on fixed cryoconite samples (4\% formaldehyde) back in the lab in the Czech Republic.

\subsection{Density estimations of microalgae}

Microalgal biovolumes were estimated by epifluorescence microscopy for cyanobacteria and light microscopy for eukaryotic microalgae as described by Kaštovská et al. (2005). After settling of the sediment for at least 30 minutes the supernatant was removed with a syringe and kept for further dilutions. Due to the current of meltwater through cryoconite holes, the sediment is already well selected towards high sedimentation rates and the supernatant appeared clear and no remaining particles were observed. The remaining water-saturated wet sediment was used for estimations of the microalgae densities and the water content. For the counting, $0.25 \mathrm{~g}$ of wet sediment was diluted with $3 \mathrm{~mL}$ of the meltwater from the analyzed sample and crushed in order to homogenize the granules. Then, $40 \mu \mathrm{L}$ of this suspension was transferred onto a microscopic slide and at least 200 cells were counted and measured. Basic geometric equations for cylinders with hemispherical ends and spheres were applied to calculate the biovolume per wet mass of sediment. After measuring the total sediment mass in the predefined area, it was possible to calculate the densities as biovolumes per area $\left(\mu \mathrm{m}^{3} \mathrm{~cm}^{-2}\right.$ of cryoconite sediment layer). Additionally, the biovolumes were separated into different size classes based on estimated limits for grazing by filtrating organisms. The estimations are based on the common size of grazers (100-200 $\mu \mathrm{m}$ ) and their feeding apparatuses (buccal tube of tardigrades 5-10 $\mu \mathrm{m}$, filtrating organ opening of rotifers $25-50 \mu \mathrm{m})$ in the samples of this study. The division of filtering classes is mainly based on measurements of the feeding apparatuses of the filter-feeding rotifers in our own samples. Additionally, Hino and Hirano (1980) found a linear relationship between the maximum ingestible particle size and the body length in the rotifer Brachionus plicatilis. For $200 \mu \mathrm{m}$ long specimen they found a maximum ingestible particle size of about $21 \mu \mathrm{m}$. Microalgal biovolumes of single cells $\leq 10 \mu \mathrm{m}$, single cells $>10 \mu \mathrm{m}$, colonies $\leq 10$ cells, colonies $>10$ cells, filaments $\leq 25 \mu \mathrm{m}$, and filaments $>25 \mu \mathrm{m}$ were separated in order to visualize the spectrum of possible food items. The mean and median sizes of the colonies and cells were estimated. All densities are given in $\mu \mathrm{m}^{3} \mathrm{~cm}^{-2}$ of cryoconite sediment layer, since photosynthetic activity is thought to be limited to the first few micrometers of the sediment surface. General oxygen profiles in sediments, obtained with microsensors, showed photosynthetic activities 
at sediment depths only below $0.5-1 \mathrm{~mm}$ (e.g., Revsbech et al., 1986). For cryoconite sediments a study by Telling et al. (2011) showed that a net autotrophic system is only maintained in sediment layers $<3 \mathrm{~mm}$. Errors of this method related to the dilution, determination, measurements and counting are described by Mueller et al. (2001). For the study of population dynamics, the microscopic approach is preferred to molecular methods since the taxonomic resolution is not as important as accurate density estimations of functional groups. A PCR bias in genetic methods would, however, lead to a higher uncertainty in density estimations. Nevertheless, the cyanobacterial community structures of Hørbyebreen (HC) and Nordenskiöldbreen (NR) were compared with measurements of the prokaryotic community structure based on MiSeq Illumina sequencing of the V3-V4 regions of the 16S rRNA genes in 2012. This additional genetic method helps to validate the microscopy-derived estimates and gives an estimate of the abundances of additional bacteria and cyanobacterial genera. It is mainly used to compare the genus distributions between the two glaciers. The sampling sites were located at $78.63^{\circ} \mathrm{N}, 17.13^{\circ} \mathrm{E}$ on Nordenskiöldbreen and at $78.76^{\circ} \mathrm{N}, 16.46^{\circ} \mathrm{E}$ on Hørbyebreen. The locations are near to the Hørbyebreen (HC) and Retretøya (NR) sampling sites. The most dominant genera were then compared to previously found nifH genes, important for nitrogen fixation, in the NCBI database (Geer et al., 2010). The functional cyanobacteria groups in this study are Nostocales as heterocystous cyanobacteria and Oscillatoriales as filamentous cyanobacteria without heterocysts but with the ability to stabilize cryoconite granules. The eukaryotic microalgal groups are Chlorophyceae and Zygnematophyceae. Diatoms and Chroococcales were excluded from the analysis due to their low abundances and the related inaccuracy of biovolume estimations in dilutions.

\subsection{S rRNA gene sequencing and sequence analysis}

The highly variable V3-V4 region of the 16S rRNA gene was amplified with the bacterial primers S-D-Bact-0341-b-S-17 forward and S-D-Bact-0785-a-A-21 reverse, with overhang Illumina adaptors attached to the primer sequences, creating a single amplicon of about $460 \mathrm{bp}$ (Klindworth et al., 2013). The reaction was carried out in $50 \mu \mathrm{L}$ volumes, containing $0.3 \mathrm{mg} \mathrm{mL}^{-1}$ bovine serum albumin, $250 \mathrm{mM}$ dNTPs, $0.5 \mathrm{mM}$ of each primer, $0.02 \mu \mathrm{L}$ of Phusion high-fidelity DNA polymerase (Finnzymes OY, Espoo, Finland) and $5 \times$ Phusion HF buffer, containing $1.5 \mathrm{mM} \mathrm{MgCl} 2$. The following PCR conditions were used: initial denaturation at $95^{\circ} \mathrm{C}$ for $5 \mathrm{~min}$, followed by 25 cycles consisting of denaturation $\left(95^{\circ} \mathrm{C}\right.$ for $\left.40 \mathrm{~s}\right)$ annealing $\left(55^{\circ} \mathrm{C}\right.$ for $\left.1 \mathrm{~min}\right)$ and extension $\left(72^{\circ} \mathrm{C}\right.$ for $1 \mathrm{~min}$ ) and a final extension step at $72^{\circ} \mathrm{C}$ for $7 \mathrm{~min}$. The amplified DNA was sequenced using the Illumina MiSeq platform at Liverpool Centre for Genomics Research and generated $2 \times 300 \mathrm{bp}$ overlapping paired-end reads. The $16 \mathrm{~S}$ sequences were further processed using the mothur (v.
1.35) pipeline (Schloss et al., 2009). Chimeric sequences were identified and removed using UCHIME (Edgar et al., 2011). Reads were clustered into operational taxonomical units (OTUs), based on at least $97 \%$ sequence similarity, and assigned taxonomically against the SILVA database (Quast et al., 2013).

The sequences are stored at NCBI and available under accession number PRJNA296475.

\subsection{Environmental variables}

As proxies for the age and stability of the hole, water depth was measured with a ruler immediately after the sampling. The water content of the sediments was calculated as the percentage of weight loss of water-saturated sediments after drying at $50^{\circ} \mathrm{C}$ for $12 \mathrm{~h}$. The total organic matter (TOM) content was estimated as the weight loss of the dried sediments after dry combustion at $450{ }^{\circ} \mathrm{C}$ for $5 \mathrm{~h}$. The sediment load was estimated as the total mass of cryoconite sediments within a defined area. The sediment coverage of Nordenskiöldbreen (NC) and Hørbyebreen (HC) was estimated using aerial pictures taken by a multicopter using ImageJ after Irvine-Fynn et al. (2010). The elevation and distance to the closest deglaciated land was measured using a handheld GPS and topographic maps from 1990, with an error of about $25 \mathrm{~m}$ related to the mapping and an underestimation of approximately $75 \mathrm{~m}$ related to glacial retreats. The time of the sampling was calculated as summer degree days (SDDs). SDDs are commonly used to model the surface runoff of glaciers (Braithwaite, 1995) and thus a good indicator of the environmental disturbance on the supraglacial system related to time. As a proxy for nutrient inputs the impact of birds was estimated as ranks between 0 and 3 based on (1) the presence of birds or, for example, bird excrement or carcasses and (2) the distance to bird colonies. An impact of 0 refers to a site with no signs of birds or excrement, and far away from any bird colonies, whereas an impact of 3 means a site with birds resting on the glacier with excrement around and a bird colony nearby. For the chemical analyses of cryoconite sediments, ammonium and ammonia $\left(\mathrm{NH}_{3}-\mathrm{N}\right.$ and $\left.\mathrm{NH}_{4}^{+}-\mathrm{N}\left(\mathrm{NH}_{X}-\mathrm{N}\right)\right)$ were measured by the gas diffusion method using a FIA LACHAT QC 8500 (Lachat Instruments, USA) after Karlberg and Twengstrom (1983) (application note ASN 50-0187, Tecator, ISO 11732), and the total mineralized phosphorous (TP) was measured after Kopáček and Hejzlar (1995), while bioavailable orthophosphate $\left(\mathrm{PO}_{4}^{2-}-\mathrm{P}\right)$ was measured photometrically after Mehlich (1984). For the chemical analysis of the meltwater, total organic and inorganic carbon (TOC, TIC) were measured from a filter using an elemental analyzer. Due to the stability of chemical properties in cryoconites, previously observed (Porazinska et al., 2004), all nutrients were measured once during the season and in a mix of sediments from different cryoconites of each site. 


\subsection{Statistical analysis}

In order to test for differences between the sites and possible controls, multivariate and univariate statistics were applied using different statistical programs. Log-transformed data were used for all ordination analyses. Analyses of similarities (ANOSIM) were performed using Past (Hammer et al., 2001) for comparing the community structures between the sites, controls and treatments, as well as different sampling times within the same cryoconite hole using Bray-Curtis dissimilarities. The null hypothesis was rejected if $p<0.05$. $p$ values of multiple tests were corrected according to the false discovery rate. A one-way ANOVA followed by a Tukey honest significant difference test was applied, using R (R Development Core Team, 2008), to test for differences of environmental variables, and mean and median sizes of microalgae between the sampling sites. For direct correlation between grazers and microalgae, correlation analysis of $\log (x+1)$ transformed densities and standardized microalgal densities $\left(x \times 10^{-6}\right)$ were applied using R. Multiple linear regression models using untransformed (Oscillatoriales), and $\log (x+1)$ transformed (other microalgae) data and assuming a Poisson distribution were used to assess the effects of grazer densities on the mean and median sizes of the different microalgal groups.

For a more detailed analysis of possible biotic interactions, a principal component analysis (PCA) was performed using CANOCO 5.03. A partial redundancy analysis (RDA) was applied in order to test for environmental controls, using CANOCO 5.03, as a linear constrained ordination method. Prior to the ordination, a detrended correspondence analysis (DCA) was used to test whether a linear ordination is appropriate. A gradient length of 2.4 SD supported a linear model. The interactive forward-selection covariates analysis was used in order to build a model, which only includes the best explanatory variables and to avoid the problem of colinearity. After the ordination, a permutation test based on $r^{2}$ values with 999 permutations enabled testing the amount of variation explained by the model and the explanatory variables. In order to test for environmental controls, a model using the environmental variables as explanatory variables and the spatial variables as covariables was used.

\section{Results}

\subsection{Differences between sites}

Differences between the sites were found in their environments and their community structures as shown in Fig. 2a, b, c and Table 2. Hørbyebreen (HC) shows the highest proportion and concentration of cyanobacteria $\left(88 \%, 238 \times 10^{-6} \mu^{3} \mathrm{~cm}^{-2}\right)$ compared to eukaryotic green microalgae $\left(31 \times 10^{-6} \mu \mathrm{m}^{3} \mathrm{~cm}^{-2}\right)$ and the highest densities of all microalgae based on the micro-
Table 2. Statistically significant (corrected $p<0.05$ ) differences between the sites in their community structures (ANOSIM results) and environments (ANOVA results).

\begin{tabular}{|c|c|c|c|c|c|}
\hline & $\mathrm{HC}$ & $\mathrm{NC}$ & NI & NL & NR \\
\hline \multicolumn{6}{|l|}{ Community } \\
\hline $\mathrm{E}$ & A & G & $\mathrm{G}$ & $\mathrm{G}$ & A \\
\hline $\mathrm{HC}$ & & A & A & $\mathrm{A}, \mathrm{G}$ & A \\
\hline $\mathrm{NC}$ & & & A & - & A \\
\hline NI & & & & - & A \\
\hline NL & & & & & A \\
\hline NR & & & & & - \\
\hline \multicolumn{6}{|l|}{ Environment } \\
\hline $\mathrm{E}$ & $\mathrm{De}$ & $\mathrm{Om}$ & - & - & - \\
\hline $\mathrm{HC}$ & & $\mathrm{Om}$ & - & $\mathrm{Sm}$ & - \\
\hline $\mathrm{NC}$ & & & $\mathrm{De}$ & $\begin{array}{r}\text { Sm, Wc, } \\
\text { Om, De }\end{array}$ & - \\
\hline NI & & & & $\mathrm{Om}$ & $\mathrm{De}$ \\
\hline NL & & & & & - \\
\hline NR & & & & & - \\
\hline
\end{tabular}

scopic counts $\left(270 \times 10^{-6} \mu \mathrm{m}^{3} \mathrm{~cm}^{-2}\right)$ (Fig. 2a). The Retrettøya (NR) community differs from all other sites because of a microalgal community dominated by green microalgae $\left(209 \times 10^{-6} \mu^{3} \mathrm{~cm}^{-2}\right)$ (Fig. 2a). The sites NI (Nordenskiöldbreen plateau) and NL (Nordenskiöldbreen supraglacial lake), which were furthest away from deglaciated land, have the highest proportion of Oscillatoriales $(56$ and $71 \%)$. The other sites are rather similar, with a cyanobacteria-dominated community (71-68\%).

16S rRNA sequence based abundances of cyanobacteria in 2012 show, overall, similar patterns as observed in 2014 via epifluorescence microscopy (Fig. 2a, c). Cyanobacteria constitute a substantial part of the prokaryotic community (21 and $26 \%$ on Nordenskiöldbreen, and $39 \%$ on Hørbyebreen of all $16 \mathrm{~S}$ reads) (Fig. 2c). The most dominant cyanobacteria in the 16S reads were Arthronema sp., Microcoleus sp. and Nostoc spp.; Calothrix spp., Symploca sp., and Leptolyngbya sp. were also abundant genera (Fig. 2c).

The rest of the bacterial diversity in the $16 \mathrm{~S}$ reads is mainly represented by Proteobacteria, Bacteroidetes, and Actinobacteria. Other potentially diazotrophic bacteria included bacteria of the genera Clostridium and Ralstonia. The only additional phototrophic bacteria found in the $16 \mathrm{~S}$ reads was the green non-sulfur bacteria group of Chloroflexi $(<1 \%)$. In a few samples of this study (1-3 per glacier), microalgae were identified to genus level by microscopy. Cyanobacteria of the genera of Nostoc, Leptolyngbya, Phormidium, and Microcoleus prevailed in the microscopic counts. The most abundant cyanobacteria genera in the $16 \mathrm{~S}$ reads, Arthronema sp. and Calothrix sp., were not recognized via microscopy. The most dominant green microalgae included Chlamydomonas 
(a)

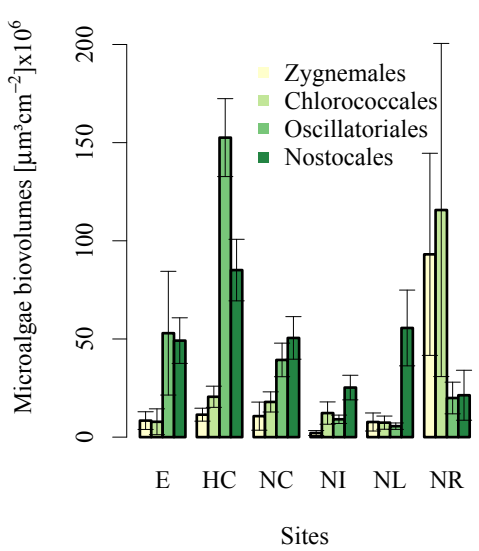

(b)

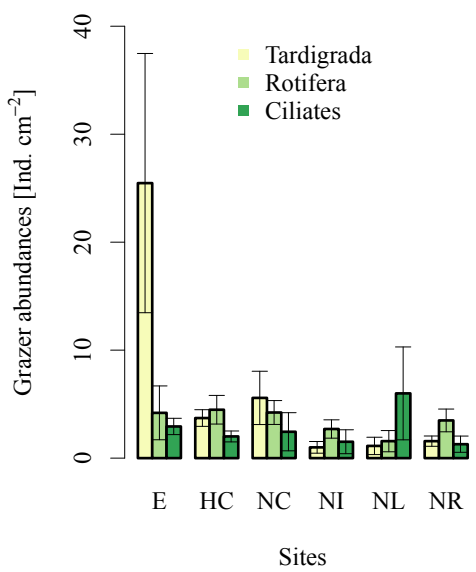

(c)

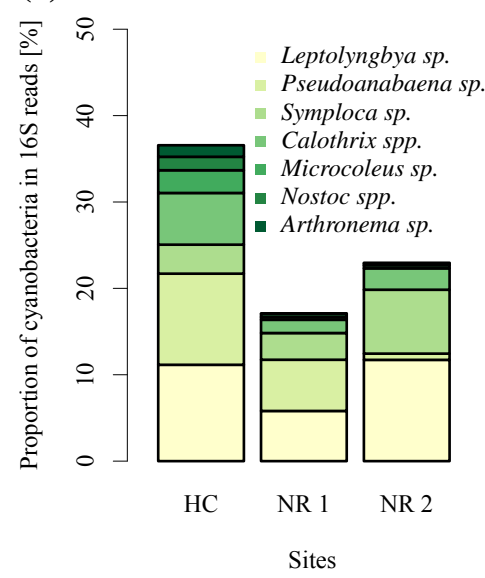

Figure 2. Mean densities in cryoconite sediment layers of microalgae (a) in $\left(\mu \mathrm{m}^{3} \mathrm{~cm}^{-2}\right) \times 10^{-6}$ and grazers (b) in individuals per square centimeter for the different sites (E: Ebbabreen; HC: Hørbyebreen; NC: Nordenskiöldbreen; NI: Nordenskiöldbreen plateau; NL: supraglacial pond on Nordenskiöldbreen; NR: Retrettøya). The error bars indicate the standard errors. Panel (c) shows the proportion of different cyanobacterial genera within all 16S sequences from 2012 on Hørbyebreen (HC) and Nordenskiöldbreen (no. 1, no. 2).

nivalis, Ancylonema nordenskioldii, Cylindrocystis brebissonii and Mesotaenium berggrenii.

Regarding the grazers, in most sites tardigrades and rotifers were equally abundant (1-5 ind. $\mathrm{cm}^{-2}$ ) (Fig. 2b). Only on Ebbabreen (E) did the grazer community have higher densities of tardigrades $\left(25\right.$ ind $\mathrm{cm}^{-2}$ ) compared to the other sites (Fig. 2b). A seasonal change in the community structure was found between the first and last sampling dates on Hørbyebreen (HC) $(p=0.0384)$, but no difference between the repeatedly sampled cryoconite holes and their controls and no seasonal variation in the community structures were found.

In a few samples, invertebrates were identified to genus or species level by microscopy. The most dominant rotifers belonged to the Macrotrachella insolita group, ranging between 1 (NL) and 4 (HC) ind. $\mathrm{cm}^{-2}$. In particular, M. musculosa made up the largest proportion of this group. Also, a few individuals of Adineta vaga (0.4 (NR)-0.9 (E) ind. $\left.\mathrm{cm}^{-2}\right)$ and Encentrum sp. (0 (NL, NR)-0.3 (E) ind. $\mathrm{cm}^{-2}$ ) were found. The most frequent tardigrades found on all sampled glaciers were Pilatobiotus recamieri and Hypsibius dujardini. Hypsibius cf. arcticus and the genus Isohypsibius were also rarely found. Tardigrade species were not identified immediately in the field and were thus not quantified. Ciliates were not identified to species or genera level.

A more precise description of differences in environmental variables for each site is given in Table 3. Overall, the variation in environmental factors and community structures within one glacier (Nordenskiöldbreen: NC - main site, $\mathrm{NR}, \mathrm{NI}, \mathrm{NL}$ ) is often higher than the variation between the glaciers (Tables 2 and 3).

The sites NC and HC have similar nitrogen and phosphorus concentrations and ratios. The nutrient data for NR and
NI showed generally higher $\mathrm{N}: \mathrm{P}$ ratios. The TOC : TIC ratio on Hørbyebreen (HC) compared to Nordenskiöldbreen (NC) seems to be higher.

Hørbyebreen is characterized by the lowest water depth and highest sediment coverage, but Nordenskiöldbreen and particularly the Retrettøya site (NR) had the highest sediments loads (sediment thickness in cryoconite), the highest water content and the highest concentration of organic matter. The deepest cryoconite holes were found on the upper plateau of Nordenskiöldbreen (NI). The cryoconite holes next to Retrettøya are closest to deglaciated land and have the highest sediment load and impact of birds, since they were right next to a colony of Arctic terns. Also, a large number of black-legged kittiwakes use the glacier to rest on when the low tide sweeps the icebergs out of the fjord. The supraglacial lake is the farthest from any deglaciated land and cryoconite holes in this area were particularly deep, with the lowest sediment load and organic matter content.

\subsection{Possible biotic interactions}

Principal component analysis (PCA) (Fig. 3) was used to look for possible correlations between all groups and linear Pearson's correlation (Table 4) for the correlation between invertebrate grazer densities and their proposed prey. The abundance of grazers was significantly correlated with an increase in Zygnemales concentrations $\left(r^{2}=0.29-0.31\right)$ (Table 4). Rotifers were positively correlated with both Zygnemales and Chlorococcales, and tardigrades only with the usually larger Zygnemales (Table 4). In contrast, both groups of cyanobacteria (Oscillatoriales and Nostocales) were not correlated with either tardigrades or rotifers.

The PCA shows that the first axis explains most of the variation for green microalgae and grazers, but both of the 
Table 3. Environmental variables for each site as ranges or averages \pm the standard error. Bold numbers indicate particularly high values and italic numbers indicate low values. $n$ indicates the samples size for the different kind of analysis. Abbreviations for the different parameters are given in brackets.

\begin{tabular}{|c|c|c|c|c|c|c|c|}
\hline Site & & $\mathrm{HC}$ & $\mathrm{NC}$ & NI & NR & $\mathrm{E}$ & NL \\
\hline$n$ & & 16 & 10 & 6 & 5 & 6 & 6 \\
\hline Elevation $(e)$ & m.a.s.l. & $170-230$ & $150-200$ & $20-50$ & $160-525$ & 200 & \\
\hline Sediment load (sedmass) & mg w.w. $\mathrm{cm}^{-2}$ & $238 \pm 15$ & $277 \pm 23$ & $195 \pm 27$ & $396 \pm 162$ & $212 \pm 18$ & $161 \pm 15$ \\
\hline Water content (water) & $\mathrm{M}(\%)$ & $48 \pm 2$ & $\mathbf{5 1} \pm 4$ & $50 \pm 5$ & $47 \pm 2$ & $51 \pm 3$ & $39 \pm 6$ \\
\hline Organic matter (om) & $\mathrm{mg} \mathrm{kg}^{-1}$ & $434 \pm 14$ & $\mathbf{1 1 8 4} \pm 498$ & $607 \pm 83$ & $603 \pm 62$ & $293 \pm 81$ & $207 \pm 134$ \\
\hline Water depth (depth) & $\mathrm{cm}$ & $0.4-14.5$ & $0.1-28$ & $15.8-49$ & $1.7-33$ & $8-43$ & $8-43$ \\
\hline Distance to deglaciated land & $\mathrm{m}$ & $20-400$ & 850 & 2800 & $50-150$ & $50-1400$ & 3300 \\
\hline Sediment coverage (sediment) & $\mathrm{A}(\%)$ & $\mathbf{1 2 . 6 9} \pm 0.53$ & $8.79 \pm 0.39$ & & & & \\
\hline Impact of birds (birds) & rank & $0-1$ & 2 & 1 & 3 & $0-2$ & 1 \\
\hline \multicolumn{8}{|l|}{ Particulate nutrients in sediments } \\
\hline $\mathrm{N}$ & & 3 & 4 & 1 & 1 & & \\
\hline Bioactive $\mathrm{PO}_{4}^{2-}-\mathrm{P}$ & $\mathrm{mmol} \mathrm{kg}^{-1}$ & $0.21 \pm 0.02$ & $0.15 \pm 0.02$ & $0.19 \pm \mathrm{NA}$ & $0.20 \pm \mathrm{NA}$ & & \\
\hline Total $P(\mathrm{TP})^{4}$ & $\mathrm{mmol} \mathrm{kg}{ }^{-1}$ & $\mathbf{6 . 8 1} \pm 0.43$ & $6.11 \pm 0.86$ & $4.88 \pm \mathrm{NA}$ & $5.46 \pm \mathrm{NA}$ & & \\
\hline $\mathrm{NH}_{x}-\mathrm{N}$ & $\mathrm{mmol} \mathrm{kg}^{-1}$ & $90.31 \pm 12.38$ & $77.46 \pm 21.43$ & $89.76 \pm N A$ & $110.36 \pm N A$ & & \\
\hline $\mathrm{NH}_{x}-\mathrm{N} / \mathrm{TP}$ & & $13.56 \pm 2.47$ & $14.56 \pm 4.56$ & $18.40 \pm N A$ & $20.20 \pm N A$ & & \\
\hline $\mathrm{PO}_{4}-\mathrm{P} / \mathrm{TP}$ & & $0.03 \pm 0.00$ & $0.03 \pm 0.01$ & $0.04 \pm \mathrm{NA}$ & $0.04 \pm \mathrm{NA}$ & & \\
\hline \multicolumn{8}{|l|}{ Dissolved carbon in water } \\
\hline $\mathrm{N}$ & & 1 & 5 & & & & \\
\hline Total organic carbon (TOC) & ppb & $\mathbf{4 2 8 7} \pm 45$ & $2420 \pm 238$ & & & & \\
\hline Inorganic carbon (TIC) & $\mathrm{ppb}$ & $622 \pm 2$ & $\mathbf{9 4 6} \pm 262$ & & & & \\
\hline Total carbon $($ TOC + TIC) & ppb & $4907 \pm 45$ & $3365 \pm 122$ & & & & \\
\hline
\end{tabular}

Table 4. Correlation table with Pearson's $r^{2}$ values and corrected $p$ values between microalgae and invertebrate grazers. Significant values are marked in bold.

\begin{tabular}{lcrr}
\hline & & Tardigrada & Rotifera \\
\hline Chlorococcales & $r^{2}$ & 0.141 & 0.232 \\
& $P$ & 0.471 & 0.075 \\
Zygnemales & $r^{2}$ & $\mathbf{0 . 3 1 1 8}$ & $\mathbf{0 . 2 8 8 5}$ \\
& $P$ & $\mathbf{0 . 0 1 7 1}$ & $\mathbf{0 . 0 1 9 6}$ \\
Oscillatoriales & $r^{2}$ & -0.044 & -0.063 \\
& $P$ & 0.796 & 0.796 \\
Nostocales & $r^{2}$ & 0.044 & -0.108 \\
& $P$ & 0.796 & 1.00 \\
\hline
\end{tabular}

cyanobacterial groups are mainly explained by the second axis (Fig. 3). This indicates different controls on eukaryotic microalgae and grazers, in contrast to cyanobacteria. Besides the positive correlation between grazers and eukaryotic microalgae, the PCA suggests another positive correlation between the green microalgae and consumer groups (ciliates, rotifers and tardigrades).

The distribution of mean and median sizes of different microalgae as possible food sources for grazers (Figs. 2 and $4 a, b)$ show in general that most eukaryotic microalgae are larger than the suggested filtration limit for rotifers, and most cyanobacteria form colonies which are larger than $10 \mu \mathrm{m}$ (cells) or longer than $30 \mu \mathrm{m}$.

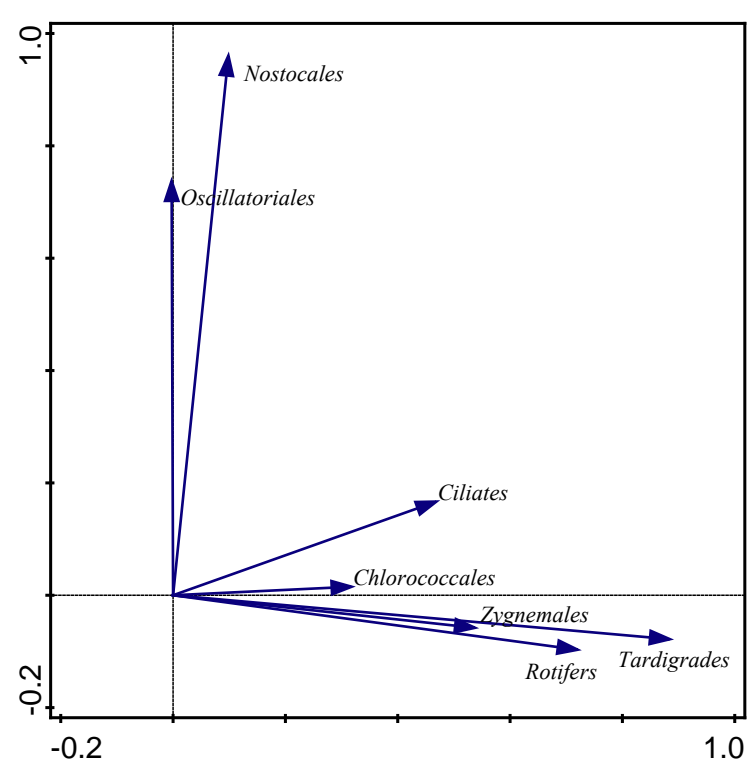

Figure 3. PCA biplot of all organisms collected in this study. Euclidean dissimilarities were used. The data are log-transformed and microalgal biovolumes were standardized by multiplication by $10^{-6}$.

An ANOVA showed that the communities of the supraglacial pond (NL) have significantly longer filaments of Oscillatoriales and a generalized linear model assuming a 

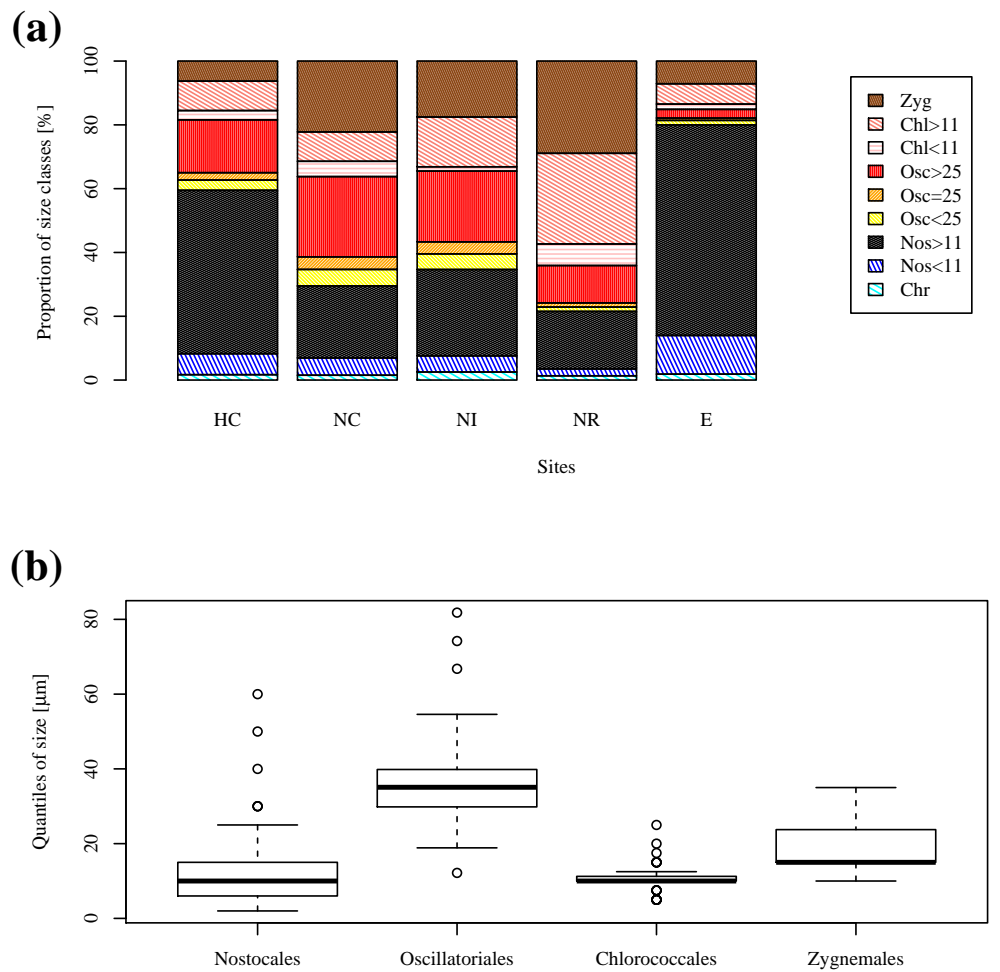

Figure 4. (a) Median and quantiles of the biovolume proportion of suggested size classes and (b) the cell number proportion of the median length (Zygnemales), diameter (Chlorococcales), colony size (Nostocales), and mean length (Oscillatoriales) as smaller $(<)$ or bigger $(>)$ than a certain threshold in micrometers. The abbreviations used in (a) refer to Chroococcales (Chr; may include single-cell Nostocales), Nostocales (Nos), Oscillatoriales (Osc), Chlorococcales (Chl), and Zygnemales (Zyg).

Poisson distribution shows that the median length of Zygnemales is significantly different between the different sites.

Multiple linear regressions with $\log (x+1)$-transformed (Nostocales) and untransformed (Oscillatoriales) data and generalized multiple linear regressions assuming a Poisson distribution (Zygnemales, Chlorococcales) show that the densities of the filtrating rotifers are negatively related to the average length of Oscillatoriales and the median length of Zygnemales (Table 5). Ciliates are positively correlated with the mean size of Oscillatoriales.

\subsection{Environmental controls}

Possible environmental controls were tested by redundancy analysis (RDA). Firstly, a RDA with temporal (time of sampling) and spatial (glacier, and place on glacier) variables as explanatory variables showed that these variables can only explain $10.7 \%$ of the total variation. The spatial variables in this model explained $84.9 \%$ of the variability. In total, it appears that the cryoconite communities are influenced by spatial and, to a smaller degree, temporal variation. The part of explained variation in the final model is shown in Table 6.

In a partial RDA, all environmental variables and time were used as explanatory variables and spatial variables were used as covariables. After interactive forward-selection co- variates analysis, a model with three significant explanatory variables remained, as shown in Table 7. The impact of birds (bird) $(17.5 \%)$, elevation $(14.1 \%)$ and sediment load (sedmass) $(10.5 \%)$ explained most of the variation in the model $(42.2 \%)$.

The RDA biplot (Fig. 5) shows that the sediment load strongly decreases with elevation. If no bird detritus was present, cyanobacteria were dominant. Eukaryotic microalgae (Chlorophyceae and Zygnematophyceae) are positively related to the sediment load. The grazer abundances are positively related to possible fertilization by birds. All axes of the biplot explain a significant $(p=0.02, F=2.9)$ part of the total variation.

\section{Discussion}

\subsection{Microalgae distribution}

The current study showed a high spatial variability in the abundance of different microalgal groups and a high distinction between green microalgae and cyanobacteria in the RDA and PCA. High ratios of eukaryotic microalgae to cyanobacteria were observed in environments close to the sea, deglaciated land, or bird colonies with high nitrogen lev- 
Table 5. Regression table for linear regression models with median and mean sizes of microalgae as dependent variables and grazer densities as explanatory variables. The bold numbers indicate significant correlations.

\begin{tabular}{llrrr}
\hline & & Rotifera & Tardigrada & Ciliates \\
\hline Nostocales colony size & $p$ & 0.9622 & 0.9622 & 0.9622 \\
& Estimate & 0.005 & -0.001 & 0.002 \\
Oscillatoriales length & $p$ & $\mathbf{0 . 0 0 8 3}$ & 0.9622 & $\mathbf{0 . 0 1 4 9}$ \\
& Estimate & $\mathbf{- 0 . 0 1 6}$ & 0.0004 & $\mathbf{0 . 0 1 3 6}$ \\
Chlorococcales diameter & $p$ & 0.6072 & 0.9622 & 0.9622 \\
& Estimate & -0.011 & 0.0004 & -0.005 \\
Zygnemales length & $p$ & 0.1032 & 0.9622 & 0.6072 \\
& Estimate & -0.0158 & -0.0001 & 0.0093 \\
\hline
\end{tabular}

Table 6. Results for an RDA with spatial and temporal variables as explanatory factors and the explained variability in each variable on the final model. The glacier variable represents the three sampled glaciers.

\begin{tabular}{lrrr}
\hline & $\begin{array}{r}\text { Explained } \\
\text { variability \% }\end{array}$ & $F$ & $P$ \\
\hline Glacier & 58.6 & 5.2 & 0.003 \\
Place on glacier & 55.8 & 4.9 & 0.008 \\
Time of sampling & 37.3 & 3.2 & 0.015 \\
\hline
\end{tabular}

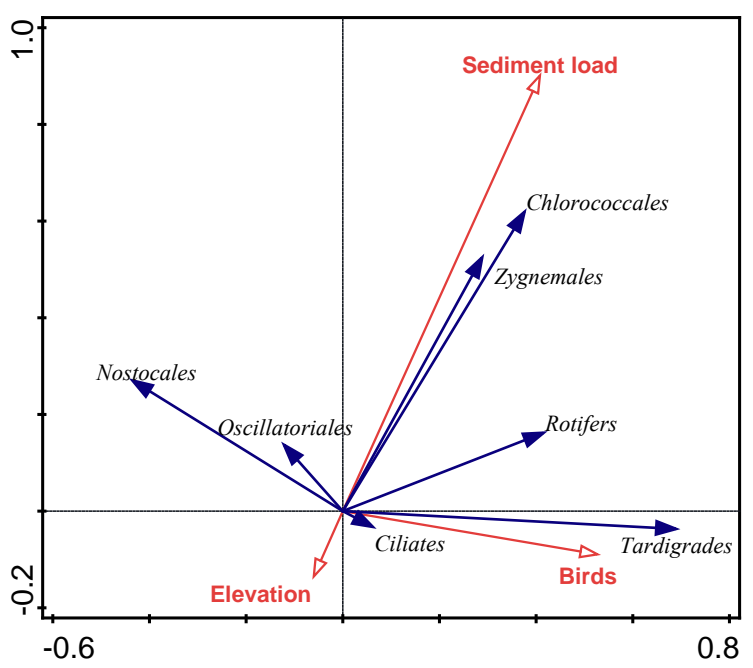

Figure 5. Biplot for the partial RDA with glacier and place as covariables, after interactive forward-selection covariates analysis. Rotifers in this figure do not include Encentrum sp. due to their low abundances.

els. Significantly higher proportions of cyanobacteria were found further away from possible nitrogen sources. Oscillatoriales were dominant over Nostocales the further they are away from any deglaciated terrain.

Three different selective mechanisms are proposed to explain the observed variation of microalgal groups among different environments. The first selection mechanism is wind
Table 7. Results for the partial RDA with glacier and place as covariables, after interactive forward-selection covariates analysis. Fourteen environmental (physical, morphological and chemical) variables are tested; only significant results are shown. Explained variability means proportion of variability explained by each variable in the total model (variability explained by all variables is $64.3 \%$ including non-significant ones). Contribution to explained variability means the proportion of a selected variable in variability explained by selected variables.

\begin{tabular}{lrrrr}
\hline Name & $\begin{array}{r}\text { Explained } \\
\text { variability } \%\end{array}$ & $\begin{array}{r}\text { Contribution } \\
\text { to explained } \\
\text { variability } \%\end{array}$ & Pseudo- $F$ & $p$ \\
\hline Birds & 17.5 & 27.3 & 7.7 & 0.001 \\
Elevation & 14.1 & 21.9 & 7.2 & 0.009 \\
Sediment load & 10.5 & 16.4 & 6.2 & 0.023 \\
\hline
\end{tabular}

transport of dust and soil particles, including cyanobacteria and nutrients (Broady, 1996; Porazinska et al., 2004). This wind transport is proposed to be selective for certain cyanobacteria groups. We propose that selection occurs because polar cyanobacteria are often associated with dust in soil, and thus easily transported by wind (Broady, 1996). Furthermore, they are well adapted to desiccation and cryoinjuries which frequently occur during wind transport and on glaciers and could explain their usual dominance in polar freshwater habitats (Tang et al., 1997; Šabacká and Elster, 2006) and in our samples. Hence, thin trichal Oscillatoriales (e.g., Leptolyngbya, Arthronema) are likely to be easily transported on glacial surfaces in this way. Nitrogen input by dust is proposed to be of rather low impact if the dust originates from adjacent slopes but have a relatively high impact if it originates from tundra soil (Stibal et al., 2006). The second selection criterion is the nitrogen input in the form of nitrate, nitrite and ammonia, or ammonium which selects for eukaryotic microalgae. In fact, green microalgae occurred mainly in cryoconite holes with a high input of bird guano and was dominant in holes with higher $\mathrm{NH}_{X}-\mathrm{N}$ concentrations and PN:TP ratios above Redfield (16:1). The most important inputs are most likely atmospheric inorganic nitrogen stored in snow and ice followed by sea spray or bird 
guano, tundra soil and moraine dust with the least hypothesized importance. While there are high inputs of tundra soil and bird guano, we propose that autochthonous $\mathrm{N}_{2}$ fixation plays an insignificant role. The third selection mechanism is the stability of the environment, where eukaryotic microalgae are better adapted to quickly changing environments due to their quick growth, photoprotection by complex adaptation processes of their photosystems, and mobility in the case of snow microalgae.

All three mechanisms together can explain the distribution described above. That is, high eukaryotic microalgae concentrations occur in an unstable environment with high concentrations of bioavailable nitrogen and a high impact of birds. High Oscillatoriales proportions are found further away from the glacier margins, but still at low concentrations due to their less efficient pathways of $\mathrm{N}_{2}$ fixation. Higher Nostocales proportions occur where nutrient inputs are limited to dust from adjacent moraines, which would transport Oscillatoriales but much less bioavailable nitrogen for the growth of eukaryotic microalgae.

Another explanation could be that the green microalgae found in this study were accidentally introduced to the cryoconite holes. Since these microalgal groups usually occur on glacial surfaces, unstable cryoconite holes with thick sediment layers at lower elevations would accumulate more supraglacial organisms by meltwater inflow.

The dominance of Arthronema sp. and Calothrix sp. in the $16 \mathrm{~S}$ reads was unexpected. Both genera are usually absent or rarely found in cryoconites (Mueller et al., 2001) and the microscopic identifications did not show high abundances of these genera in our samples. In fact, in this study, Arthronema sp. were in cryoconites at all. Arthronema gygaxiana is known to be distributed globally in freshwater and soil habitats, including glacier forefields (Casmatta et al., 2005; Frey et al., 2013). Hence, the presence of this species in our analyses from 2012 is possible. However, sequence similarity analysis of previously analyzed 16S rRNA genes of Arthronema spp. and the other dominant species in our reads using ARB (Quast et al., 2013) showed a high heterogeneity between strains. One strain was more closely related to Leptolyngbya antarctica than to all other strains. Hence, we interpret the $16 \mathrm{~S}$ reads of cyanobacteria only to the genus level. The ecological interpretations in the present paper focus on broader taxonomic levels of microscopically identified cyanobacteria.

\subsection{Geographic properties}

The valley glaciers on Svalbard typically have a substantial allochthonous input of sediment and nutrients from local sources due to their small size compared to larger ice sheets. Microalgal densities found in this study are between 1.8 (NI) and 7.8 (HC) times higher than previously measured on the Greenland ice sheet (GrIS) (Stibal et al., 2006, 2008, 2012b). It is clear that small valley glaciers with high sediment cov- erages and high impact of birds usually contain higher nutrient levels and thus higher biomass and biological diversity than larger ice sheets. However, the cyanobacterial proportion within the phototrophic cells $(73 \%)$ is comparable with the findings from the GrIS (66\%) (Stibal et al., 2006).

Eukaryotic microalgae contributed biovolumes of 14$32 \mu \mathrm{m}^{3} \mathrm{~cm}^{-2} \times 10^{-6}(14-29 \%)$ at most sites, except near Retrettøya (NR) $\left(209 \times 10^{-6} \mu \mathrm{m}^{3} \mathrm{~cm}^{-2}, 83 \%\right)$, where the contribution was small. Similar values were observed by Stibal et al. (2006) on the GrIS. In direct comparison, most sites in the present study are enriched in cyanobacteria compared to the GrIS, except for the exceptional site near Retrettøya. Only $17 \%$ of the phototrophic cells at this site were cyanobacteria, which would rather fit with the values of medial moraines on the GrIS (24\%) measured by Stibal et al. (2006), but the general concentration of phototrophs at Retrettøya is 2 orders of magnitude higher compared to the medial moraines. This finding may indicate a system with high productivity due to sufficient nutrient input and sunlight compared to the moraines or more isolated cryoconites but a different community structure. Most of the eukaryotic microalgae found are known as ice or snow microalgae, and possible reasons for their accumulation in unstable cryoconite holes have been described in the last chapter.

Spatial variability between close glaciers was also found. Our data indicate high variability in the community structure within various parts of one glacier. Stibal et al. (2012b) found different environmental controls on microbial communities in cryoconite holes at different altitudes on the GrIS. Chemical variables were mostly explained by physical and/or geographic parameters. The altitude, slope, distance to the closest deglaciated land, debris coverage and suggested ecological zones (glacier margin, bare ice, slush) explained most of the variability within the microbial community structure and the measured chemical parameters. Since the present study did not cover a comparable range of slopes, no effect of the slope was found. For the debris coverage, elevation and distance to the closest deglaciated land, the proxies measured and used were elevation and sediment load for the habitat stability and age and bird impact for external nutrients. Each showed a significant impact on the microalgal community structure and on their proposed consumers (grazer). Similar environmental controls on grazer abundances have been observed in Antarctica (Porazinska et al., 2004) with significant effects of sediment load and elevation.

The low abundances of cyanobacteria on glacial surfaces (Lutz et al., 2014) also suggest a weaker adaptation to quickly changing and unstable environments. Such a negative relation between cyanobacteria presence and high sediment loads in lower elevations in cryoconite holes is clearly visible. It is well know that cyanobacteria are slow growing (Tang et al., 1997), which means that they are more sensitive to disturbance, as shown by the negative relation with the sediment load. However, eukaryotic microalgae are fast growing and more resistant to disturbance by sediment load. 
In fact, Cook et al. (2010) found that cryoconite granules usually form a single grain layer between 0.04 and $0.20 \mathrm{~g} \mathrm{~cm}^{-2}$ as a result of lateral thermal conductivity if time allows. Thereby, the absorbed solar radiation is conducted laterally to the ice walls of the cryoconite hole, resulting in an increasing area and a decreasing sediment thickness. This means that a thick sediment layer indicates a younger, unstable cryoconite hole. The sediment load of the present study ranged between 0.161 at NI and $0.396 \mathrm{~g} \mathrm{~cm}^{-2}$ at NR. These values are, compared to Cook's et al. (2010) study, on the higher end and indicate rather unstable environments. Furthermore, some microalgal cells might be recently mixed into deeper layers of the sediment.

\subsection{Nutrient inputs}

The external nutrient inputs by birds together with the stability of the cryoconite holes play an additional role. The $\mathrm{N}$ : P ratio below 16:1 (Redfield, 1958) on Hørbyebreen and Nordenskiöldbreen suggests a nitrogen-limited environment where cyanobacteria dominate, whereas Retrettøya and the plateau of Nordenskiöldbreen with higher $\mathrm{N}$ : $\mathrm{P}$ ratios indicate, conversely, a phosphorous-limited environment where eukaryotic microalgae prevail. However, the number of replicates did not allow for reliable statistical tests on the exact nutrient levels. Also, Telling et al. (2011) found that phosphorous is generally the main limiting nutrient on glaciers and that nitrogen is usually introduced by snow and rain (atmospheric nitrogen) rather than by cyanobacterial nitrogen fixation. Previous research performed in Greenland by Stibal et al. (2006) also did not show a clear effect of nutrient levels on cryoconite hole microbial diversity and organic matter production. This research instead proposed that physical factors influence the nutrient conditions on glacial surfaces. In fact, Stibal et al. (2006) showed that soil texture, water content and $\mathrm{pH}$ are the main factors controlling microalgal community structures in supraglacial environments. In the present study, it appears that these factors did not play an important role in our small valley glaciers.

The cyanobacterial diversity seems to be controlled by completely different variables as indicated by the PCA (Fig. 3), in which eukaryotic microalgae and grazers were mostly explained by the first axis and cyanobacteria by the second axis. Considering the nitrogen fixation ability of cyanobacteria, it is clear that these organisms are dominant in nitrogen-limited environments. This is indicated by the negative relation to the impact of birds and a high $\mathrm{N}: \mathrm{P}$ ratio on the site at Retrettøya (NR) with the highest impact of birds.

\subsection{Nitrogen fixation}

Microalgae, including cyanobacteria, are an important part of the microbial community in cryoconite sediments. In fact, in our samples cyanobacteria biovolumes represent about 49$250 \mu \mathrm{m}^{3} \mathrm{~cm}^{-2} \times 10^{-6}$ of the cryoconite sediment layer. In the $16 \mathrm{~S}$ rRNA reads, $20-39 \%$ of the prokaryotic community are cyanobacteria and within the microalgae community mostly between 71 and $88 \%$. All cyanobacteria found in the current study are known to have closely related species possessing the nifH gene for nitrogen fixation. These potential diazotrophs were often dominant in nitrogen-depleted cryoconites. These findings indicate that sediment associated cyanobacteria are highly important as ecosystem engineers in cryoconites with respect to inorganic carbon and nitrogen fixation, especially in nitrogen-depleted areas.

In particular, the high abundances of cyanobacteria in the cryoconite community suggest that the nitrogen limitation in these ultraoligotrophic environments may be compensated for by atmospheric nitrogen fixation. In fact, all cyanobacteria identified via microscopy and $16 \mathrm{~S}$ sequencing are known to be related to nifH genes for nitrogen fixation in their genome (Paul et al., 2014; Starkenburg et al., 2011; Steward et al., 2004; Taghavi et al., 2013). Previous genome analysis is only lacking for Arthronema sp. However, in several studies it has also been proposed that allochthonous atmospheric nitrogen inputs are 2 orders of magnitude higher than autochthonous nitrogen fixation, which would mean that cryoconites are mainly phosphorous-limited (Hodson et al., 2010; Telling et al., 2011; Žárský et al., 2013). Nevertheless, in ultraoligotrophic samples far from the impact of nesting or resting birds, cyanobacteria are thought to be crucial for atmospheric nitrogen storage on the glacier. Telling et al. (2012) showed the importance of cyanobacterial nitrogen fixation on the GrIS. Possibly, nitrogen fixation may enhance the production of organic matter and expolymeric substances, which is proposed to support higher trophic levels, such as the metazoan grazers (Telling et al., 2011; Žárský et al., 2013) and heterotrophic bacteria (Decleyre et al., 2015).

\subsection{Temporal variability}

Temporal variability in the microalgal community structures has been measured for the first time in this study. An ANOSIM did not show any seasonal variation, but the RDA suggests a small temporal variability within one season which is masked by environmental and spatial factors. The temporal impact is statistically significant, but the explanatory importance is negligible. A similar study by Musilova et al. (2015) also found no temporal trend in the microbial community structure on the GrIS. However, their method was solely based on $16 \mathrm{~S}$ tag sequencing and replicates were lacking; thus, their results should be treated with caution. Also, the cyanobacterial proportion in the microbial community was smaller (3-29\%) compared to our study, which may be caused by a different system on the GrIS, or by different primers used. The overall community structure is fairly similar. The fact that both studies used different methods, taxa and habitats but still came to the same conclusion highly supports a cryoconite community of eukaryotes and prokaryotes which is not considerably influenced by temporal fac- 
tors. One possible reason for this temporal homogeneity is the short summer season and the strong selective pressure, such as cold temperatures, high light intensities and unstable habitats which are rather constant over the summer season.

\subsection{Microalgae size and grazing resistance}

The formation of large cyanobacteria colonies $(<10$ cells, or $>25 \mu \mathrm{m}$ ) observed in the studied cryoconite holes may have several benefits for the organisms.

Firstly, the colony size will most likely become larger than the maximum prey size of the present filtration feeders (Sand-Jensen, 2014). A previous study by Vanormelingen et al. (2009) showed that an increase in size of a colony of coenobium species can be an effective defense strategy against filtration feeders. The habitat of closely connected freshwater ponds studied by Vanormelingen et al. (2009) is well comparable to cryoconite holes with regard to their size and connectivity. In the current study, the negative correlation between the average length of Oscillatoriales trichomes and the abundance of filtrating rotifers indicates that this may also be true for cryoconites. We propose that, with increasing length of the trichomes, rotifers have a decreasing amount of ingestible food available in the system, resulting in a smaller density.

Secondly, a large colony size may be an adaptation to the typical environmental stressors in cryoconites. Previously, colonies of Nostoc sp. have been shown to be more tolerant to freezing and desiccation than smaller colonies (Li and Gai, 2007). A nutrient storage mechanism via extracellular mucus has also been proposed to be an effective strategy to cope with nutrient pulses in otherwise ultraoligotrophic environments (Li and Gao, 2007). Both mechanisms are good strategies to live with the environmental stressors in cryoconites. Another indirect advantage of long filaments is their importance in stabilizing large granules, which are important for heterotrophic bacteria, and these bacteria in turn might provide an advantage back to the microalgae (Takeuchi et al., 2001). The overall reason for the formation of colonies in cryoconites can be related to both environmental and predation-based stressors.

Ciliates are most likely unimportant as predators for microalgae due to their small size and usually bacterivorous diet. The positive relation between ciliate abundance and Oscillatoriales trichome length can be explained by several indirect effects. One possible explanation is that ciliates can act as a food source for larger grazers. If the larger grazers are absent, the microalgae and ciliates have an advantage.

Another reason could be that a lack of competition for bacteria as diet with the filtrating rotifers increases the number of ciliates. Green microalgae are, in general, relatively large and occur mostly as single cells. Grazer abundances were not correlated to their sizes (Table 7). Thus, it is proposed that grazing as a minor impact on the morphology of green microalgae.

\subsection{Invertebrate grazing}

Grazer densities showed no significant negative correlation with microalgal abundances, but they did show a positive correlation with green microalgae. This could indicate that grazing has a positive impact on green microalgal densities, perhaps by nutrient recycling, which should have the same effect as the impact of birds, or by shared environmental preferences. The latter is more likely, since the PCA (Fig. 3) showed very similar environmental gradients for green microalgae and cyanobacteria, and the grazer abundances and microalgal densities are positively related to the impact of birds. Hence, nutrient availability seems to impact both green microalgae and grazers. One explanation could be that those grazers are mainly feeding on smaller heterotrophic bacteria, and only to a lesser extent on microalgae. In this case, high nutrient levels would also support, besides the higher densities of green microalgae, high densities of heterotrophic bacteria. The bdelloid rotifer species and genera found in this study are, indeed, known to be bacterivorous (Devetter, 2009). The tardigrades found in this study are expected to be bacterivorous or algivorous based on the morphology of their buccal tube. A few grazers found during epifluorescence microscopy had cyanobacterial cells in their stomachs. In order to clarify this open question, future studies should include the densities of heterotrophic prokaryotes and an extended study of the stomach contents of grazers.

Trophic interactions between grazers are also possible, as pointed out by Cameron et al. (2012) and Zawierucha et al. (2014), but only positive correlations have been found between the major groups. The same positive correlation between tardigrade and rotifer abundances has been observed in Antarctica (Porazinska et al., 2004). This indicates, in general, shared food sources and low competition. In fact, the genera found in this study include grazers with different feeding strategies, including filtration feeders (Macrotrachella sp.), grasping feeders (Adineta cf. vaga), carnivores (Encentrum sp.), and omnivorous grasping tardigrades (Hypsibius sp., Isohypsibius $\mathrm{sp}$.), which may reduce competition. Some organisms, such as small rotifers and ciliates, can act as a food source for larger omnivorous or carnivorous species. Correlation analyses of these genera were not possible due to the low abundances of rare species and the related inaccuracy in estimation of their densities in diluted samples.

\section{Conclusions}

The spatial and temporal variability in microalgae and grazer community structures in cryoconite holes on central Svalbard has been studied. Environmental parameters, such as sediment load, elevation (proxy for cryoconite stability and age), and the impact of birds (proxy for nutrient inputs), explained most of the variation in the community structure. Different adaptations of various microalgae groups to ultraoligotrophic 
or unstable habitats are proposed to explain these effects. Grazer abundances were not found to be negatively correlated to any microalgae densities but instead to some of their sizes. We propose that grazing pressure by filtrating rotifers probably led to longer cells and colonies as adaptations to size-selective feeding.

A positive correlation between rotifers and green microalgae densities has also been found. A mainly bacterivorous diet for most of the grazers is suggested to explain this positive correlation. In addition, shared environmental preferences of green microalgae and bacteria for high nutrient levels have been hypothesized to explain this correlation. Further experiments including bacterial abundances and the stomach contents of grazers could help to test this novel hypothesis. Microalgae have been found to occur in very high abundances, with cyanobacteria making up a substantial part of the prokaryotic community, indicating their importance as ecosystem engineers. Also, high abundances of tardigrades, rotifers, and ciliates, including genera with different feeding strategies, have been found, suggesting a complex food web between more trophic levels than measured in the present study. Feeding experiments and analysis of stomach contents may help to bring a more detailed picture of this as yet scarcely known food web.

\section{The Supplement related to this article is available online at doi:10.5194/bg-13-659-2016-supplement.}

Author contributions. T. R. Vonnahme, J. Elster, J. D. Žárský, M. Devetter, and M. Šabacká contributed to the preparation of the manuscript, analysis of the data, and experimental design. J. Elster coordinated the study. The community structures were assessed by T. R. Vonnahme, M. Devetter (microscopy), and M. Šabacká (16s rRNA). Environmental parameters were measured by T. R. Vonnahme and J. D. Žárský. Nutrient analyses were performed by J. D. Žárský and M. Šabacká.

Acknowledgements. The field and lab work in the Czech Republic and on Svalbard was funded by the Ministry of Education, Youth and Sports of the Czech Republic through (1) CzechPolar - Czech polar stations, construction and logistic expenses (LM2010009) and (2) the project "Establishing of working team and conditions for education in the field of polar ecology and life in extreme environments" (no. CZ.1.07/2.2.00/28.0190), as well as through a long-term research development project of the Academy of Sciences of the Czech Republic (RVO 67985939). Project no. CZ.1.07/2.2.00/28.0190 was also funded by the European Social Fund and from the governmental budget of the Czech Republic. Furthermore, we want to thank Jan Kavan for help with the logistics, Jana Šnokhousová for her laboratory assistance, and Patrick Downes and Keith Edwards for revision of the English. Jakub Zarsky acknowledges support through project GAUK
279715.

The article processing charges for this open-access publication were covered by the Max Planck Society.

Edited by: G. Herndl

\section{References}

Bergman, B., Gallon, J. R., Rai, A. N., and Stal, L. J.: N 2 Fixation by non-heterocystous cyanobacteria, FEMS Microbiol. Rev., 19, 139-185, 1997.

Bidigare, R., Ondrusek, M. E., Kennicutt, M. C., Iturriaga, R., Harvey, H. R., Hoham, R. W., and Macko, S.: Evidence a photoprotective for secondary caretonids of snow algae, J. Phycol., 29, 427-434, 1993.

Braithwaite, R. J.: Positive degree-day factors for ablation on the Greenland ice sheet studied by energy-balance modelling, J. Glaciol., 41, 153-160, 1995.

Broady, P. A.: Diversity, distribution and dispersal of Antarctic terrestrial algae, Biodivers. Conserv., 5, 1307-1335, 1996.

Cameron, K. A., Hodson, A. J., and Osborn, A. M.: Structure and diversity of bacterial, eukaryotic and archaeal communities in glacial cryoconite holes from the Arctic and the Antarctic, FEMS Microbiol. Ecol., 82, 254-267, 2012.

Casamatta, D. A., Johansen, J. R., Vis, M. L., and Broadwater, S. T.: Molecular and morphological characterization of ten polar and near-polar strains within Oscillatoriales (Cyanobacteria), J. Phycol., 41, 421-438, 2005.

Christner, B. C., Kvitko, I. I. B. H., and Reeve, J. N.: Molecular identification of bacteria and eukarya inhabiting an Antarctic cryoconitedoi:10.1007/s00792-002-0309-0, 2003.

Cook, J., Hodson, A. J., Telling, J., Anesio, A., Irvine-Fynn, T., and Bellas, C.: The mass-area relationship within cryoconite holes and its implications for primary production, Ann. Glaciol., 51, 106-110, 2010.

Dastych, H.: The tardigrade of Poland, Monografie Fauny Polski, $17,1988$.

Decleyre, H., Heylen, K., Sabbe, K., Tytgat, B., Deforce, D., Van Nieuwerburgh, F., van Colen, K., and Willems, A.: A Doubling of Microphytobenthos Biomass Coincides with a Tenfold Increase in Denitrifier and Total Bacterial Abundances in Intertidal Sediments of a Temperate Estuary, PLoS ONE, 10, e0126583, doi:10.1371/journal.pone.0126583, 2015.

De Smet, W. H. and Van Rompu, E. A.: Rotifera and Tardigrada from some cryoconite holes on a Spitsbergen (Svalbard) glacier, Belg. J. zool., 124, 27-37, 1994

Devetter, M.: Clearance rates of the bdelloid rotifer, Habrotrocha thienemanni, a tree-hole inhabitant, Aquat. Ecol., 43, 85-89, 2009.

Donner, J.: Ordnung Bdelloidea (Rotatoria), Akademie-Verlag, Berlin, 1965.

Edgard, R. C., Haas, B. J., Clemente, J., Quince, C., and Knight, R.: UCHIME improves sensitivity and speed of chimera detection, Bioinformatics, 27, 2194-2200, 2011.

Fountain, A. G., Tranter, M., Nylen, T. H., Lewis, K. J., and Mueller, D. R.: Evolution of cryoconite holes and their contribution to 
meltwater runoff from glaciers in the McMurdo Dry Valleys, Antarctica, J. Glaciol., 50, 35-45, 2004.

Frey, B., Bühler, L., Schmutz, S., Zumsteg, A.., and Furrer, G.: Molecular characterization of phototrophic microorganisms in the forefield of a receding glacier in the Swiss Alps, Environ. Res. Lett., 8, 015033, doi:10.1088/1748-9326/8/1/015033, 2013.

Geer, L. Y., Marchler-Bauer, A., Geer, R. C., Han, L., He, J., He, S., Liu, C., Shi, W., and Bryant, S. H.: The NCBI BioSystems database, Nucleic Acids Res., 38, 492-496, 2010.

Grongaard, A., Pugh, P. J., and McInnes, S. J.: Tardigrades, and other cryoconite biota, on the Greenland ice sheet, Zool. Anz., 238, 211-214, 1999.

Hammer, Ø., Harper, D. A. T., and Ryan, P. D.: Past: Paleontological Statistics Software Package for education and data analysis, Palaeontol. Electron., 4, 1-9, available at: http: //palaeo-electronica.org/2001_1/k2/issue1_01.htm (last access: 1 September 2015), 2001.

Hino, A. and Hirano, R.: Relationship between body size of the rotifer Brachionus plicatilis and the maximum size of particles ingested, Bull. Jpn. Soc. Sci. Fish, 46, 1217-1222, 1980.

Hodson, A., Anesio, A. M., Tranter, M., Fountain, A., Osborn, M., Priscu, J., and Sattler, B.: Glacial ecosystems, Ecol. Monogr., 78, 41-67, 2008.

Hodson, A., Roberts, T. J., Engvall, A. C., Holmén, K., and Mumford, P.: Glacier ecosystem response to episodic nitrogen enrichment in Svalbard, European High Arctic, Biogeochemistry, 98, 171-184, 2010.

Irvine-Fynn, T. D., Bridge, J. W., and Hodson, A. J.: Rapid quantification of cryoconite: granule geometry and in situ supraglacial extents, using examples from Svalbard and Greenland, J. Glaciol., 56, 297-307, 2010.

Irvine-Fynn, T. D., Hodson, A. J., Moorman, B. J., Vatne, G., and Hubbard, A. L.: Polythermal glacier hydrology: A review, Rev. Geophys., 49, RG4002, doi:10.1029/2010RG000350, 2011.

Karlberg, B. and Twengström, S.: Applications based on gas diusion and flow injection analysis in focus, Tecator, J. Technol. Chem. Anal., 6, 14-15, 1983.

Kaštovská, K., Elster, J., Stibal, M., and Šantrůčková, H.: Microbial assemblages in soil microbial succession after glacial retreat in Svalbard (High Arctic), Microb. Ecol., 50, 396-407, 2005.

Kavecka, B.: Ecology of snow algae, Polish Pol. Res., 4, 407-415, 1986.

Klindworth, A., Pruesse, E., Schweer, T., Peplies, J., Quast, C., Horn, M., and Glöckner, F. O.: Evaluation of general 16S ribosomal RNA gene PCR primers for classical and next-generation sequencing-based diversity studies, Nucleic Acids Res., 41, 1$11,2013$.

Kopáček, J. and Hejzlar, J.: Semi-micro determination of total phosphorus in soils, sediments, and organic materials: A simplified perchloric acid digestion procedure, Commun. Soil. Sci. Plant Anal., 26, 1935-1946, 1995.

Kumar, K., Mella-Herrera, R. A., and Golden, J. W.: Cyanobacterial heterocysts, Cold Spring Harbor Perspectives in Biology, 2, a000315, doi:10.1101/cshperspect.a000315, 2010.

Langford, H., Hodson, A., Banwart, S., and Bøggild, C.: The microstructure and biogeochemistry of Arctic cryoconite granules, Ann. Glaciol., 51, 87-94, 2010.
Li, Y. and Gao, K.: Photosynthetic physiology and growth as a function of colony size in the cyanobacterium Nostoc sphaeroides, Eur. J. Phycol., 39, 9-15, 2007.

Lutz, S., Anesio, A. M., Villar, S. E., Benning, and L. G.: Variations of algal communities cause darkening of a Greenland glacier, FEMS Microbiol. Ecol., 89, 1-13, 2014

MacDonell, S. and Fitzsimons, S.: The formation and hydrological significance of cryoconite holes, Prog. Phys. Geog., 32, 595-610, 2008.

McIntyre, N. F.: Cryoconite hole thermodynamics, Can J. Earth Sci., 21. 152-156, 1984.

Mehlich, A.: Mehlich 3 Soil Test Extractant: A Modification of Mehlich 2 Extractant, Commun. Soil Sci. Plan., 15, 1409-1416, 1984.

Mieczan, T., Górniak, D., Świątecki, A., Zdanowski, M., and Adamczuk, M.: Vertical microzonation of ciliates in cryoconite holes in Ecology Glacier, King George Island, Polish Pol. Res., 34, 201-212, 2013.

Mueller, D. R., Vincent, W. F., Pollard, W. H., and Fritsen, C. H.: Glacial cryoconite ecosystems: a bipolar comparison of algal communities and habitats, Nova Hedwigia Beiheft, 123, 173198, 2001.

Musilova, M., Tranter, M., Bennett, S. A., Wadham, J. L., and Anesio, A.: Stable microbial community composition on the Greenland Ice Sheet, Front. Microbiol., 6, 1-10, 2015.

Nelson, D. R. and Marley, N. J.: The biology and ecology of lotic Tardigrada, Freshwater Biol., 44, 93-108, 2000.

Norwegian Polar Institute: Kartdata Svalbard 1:100 000 (S100 Kartdata), Tromsø, Norway: Norwegian Polar Institute, available at: http://data.npolar.no/dataset/ 645336c7-adfe-4d5a-978d-9426fe788ee3 (last access: 3 May 2015), 2014

Paul, R., Jinkerson, R. E., Buss, K., Steel, J., Mohr, R., Hess, W. R., and Fromme, P.: Draft genome sequence of the filamentous cyanobacterium Leptolyngbya sp. strain Heron Island J, exhibiting chromatic acclimation, Genome Announcements, 2, 1166 , doi:10.1128/genomeA.01166-13, 2014.

Porazinska, D. L., Fountain, A. G., Nylen, T. H., Tranter, M., Virginia, R. A., and Wall, D. H.: The biodiversity and biogeochemistry of cryoconite holes from McMurdo Dry Valley glaciers, Antarctica, Arctic, Antarctic, and Alpine Research, 36, 84-91, 2004.

Quast, C., Pruesse, E., Yilmaz, P., Gerken, J., Schweer, T., Yarza, P., Peplies, J., and Glöckner, F.O.: The SILVA ribosomal RNA gene database project: improved data processing and web-based tools, Nucl. Acids Res., 41, 590-596, 2013.

R Development Core Team: R: A language and environment for statistical computing, available at: http.www.R-project.org, (last access: 3 May 2015), 2008.

Rachlewicz, G., Szczucinski, W., and Ewertowski, M.: Post "Little Ice Age" retreat rates of glaciers around Billefjorden in central Spitsbergen, Svalbard, Polish Pol. Res., 28, 159-186, 2007.

Ramazotti, G. and Maucci, W.: Il Philum Tardigrada (III. Edizione riveduta e aggiornata), Memorie dell'Instituto italiano die idrobiologia, 41, 1016 pp., 1983.

Rautio, M., Dufresne, F., Laurion, I., Bonilla, S., Vincent, W. F., and Christoffersen, K. S.: Shallow freshwater ecosystems of the circumpolar Arctic, Ecoscience, 18, 204-222, 2011. 
Redfield, A. C.: The biological control of chemical factors in the environment, Am. Sci., 11, 230-221, 1958.

Remias, D., Holzinger, A., Aigner, S., and Lütz, C.: Ecophysiology and ultrastructure of Ancylonema nordenskiöldii (Zygnematales, Streptophyta), causing brown ice on glaciers in Svalbard (high Arctic), Polar Biol., 35, 899-908, 2012.

Revsbech, N. P., Madsen, B., and Jørgensen, B. B.: Oxygen production and consumption in sediment determined at high spatial resolution by computer simulation of oxygen microelectrode data, Limnol. Oceanogr., 31, 293-304, 1986.

Ricci, C. and Balsamo, M.: The biology and ecology of lotic rotifers and gastrotrichs, Freshwater Biol., 44, 15-28, 2000.

Rose, J. M. and Caron, D. A.: Does low temperature constrain the growth rates of heterotrophic Protists? Evidence and Implications for Algal Blooms in Cold Waters, Limnol. Oceanogr., 52, 886-895, 2007.

Šabacká, M., and Elster, J.: Response of cyanobacteria and algae from Antarctic wetland habitats to freezing and desiccation stress, Polar Biol., 30, 31-37, 2006.

Sand-Jensen, K.: Ecophysiology of gelatinous Nostoc colonies: unprecedented slow growth and survival in resource-poor and harsh environments, Ann. Bot.-London, 114, 17-33, 2014.

Säwström, C., Mumford, P., Marshall, W., Hodson, A., and Laybourn-Parry, J.: The microbial communities and primary productivity of cryoconite holes in an Arctic glacier (Svalbard 79 N), Polar Biol., 25, 591-596, 2002.

Schloss, P. D., Westcott, S. L., Ryabin, T., Hall, J. R., Hartmann, M., Hollister, E. B., Lesniewski, R. a., Oakley, B. B., Parks, D. H., Robinson, C. J., Sahl, J. W., Stres, B., Thallinger, G. G., Van Horn, D. J., and Weber, C. F.: Introducing mothur: Open-source, platform-independent, community-supported software for describing and comparing microbial communities, Appl. Environ. Microbiol., 75, 7537-7541, 2009.

Sinistro, R., Sánchez, M. L., Marinone, M. C., and Izaguirre, I.: Experimental study of the zooplankton impact on the trophic structure of phytoplankton and the microbial assemblages in a temperate wetland (Argentina), Limnol.-Ecol. Manage. Inland Waters, 37, 88-99, 2007.

Southwood, T. R. E. and Henderson, P. A.: Ecological methods, John Wiley and Sons, p. 269, 2000.

Starkenburg, S. R., Reitenga, K. G., Freitas, T., Johnson, S., Chain, P. S., Garcia-Pichel, F., and Kuske, C. R.: Genome of the Cyanobacterium Microcoleus vaginatus FGP-2, a Photosynthetic Ecosystem Engineer of Arid Land Soil Biocrusts Worldwide, J. Bacteriol., 193, 4569-4570, 2011.

Sterner, R. W.: Herbivores' direct and indirect effects on algal populations, Science, 231, 605-607, 1986.

Steward, G. F., Jenkins, B. D., Ward, B. B., and Zehr, J. P.: Development and testing of a DNA macroarray to assess Nitrogenase (nifH) gene diversity, Appl. Environ. Microb., 70, 1455-1465, 2004.

Stibal, M., Šabacká, M., and Kaštovská, K.: Microbial communities on glacier surfaces in Svalbard: impact of physical and chemical properties on abundance and structure of cyanobacteria and algae, Microb. Ecol., 52, 644-654, 2006.
Stibal, M., Šabacká, M., and Žárský, J.: Biological processes on glacier and ice sheet surfaces, Nat. Geosci., 5, 771-774, 2012a.

Stibal, M., Telling, J., Cook, J., Mak, K. M., Hodson, A., and Anesio, A. M.: Environmental controls on microbial abundance and activity on the Greenland ice sheet: a multivariate analysis approach, Microb. Ecol., 63, 74-84, 2012b.

Taghavi, S., Izquierdo, J. A., and van der Lelie, D.: Complete genome sequence of Clostridium sp. strain DL-VIII, a novel solventogenic Clostridium species isolated from anaerobic sludge, Genome Announcements, 1, e00605, doi:10.1128/genomeA.00605-13, 2013.

Takeuchi, N., Kohshima, S., Goto-Azuma, K., and Koerner, R. M.: Biological characteristics of dark colored material (cryoconite) on Canadian Arctic glaciers (Devon and Penny ice caps), Proceedings of the Memoirs of the National Institute of Polar Research, Special Issue, 54, 495-505, 2001.

Tang, E. P., Tremblay, R., and Vincent, W. F.: Cyanobacterial dominance of polar freshwater ecosystems: are high-latitude matformers adapted to low temperature?, J. Phycol., 33, 171-181, 1997.

Telling, J., Anesio, A. M., Tranter, M., Irvine-Fynn, T., Hodson, A., Butler, C., and Wadham, J.: Nitrogen fixation on Arctic glaciers, Svalbard, J. Geophys. Res.-Biogeo., 116, G03039, doi:10.1029/2010JG001632, 2011.

Telling, J., Stibal, M., Anesio, A.M., Tranter, M., Nias, I., Cook, J., and Hodson, A.: Microbial Nitrogen cycling on the Greenland Ice Sheet, Biogeosciences, 9, 2431-2442, doi:10.5194/bg9-2431-2012, 2012.

Vanormelingen, P., Vyverman, W., De Bock, D., Van der Gucht, K., and De Meester, L.: Local genetic adaptation to grazing pressure of the green alga Desmodesmus armatus in a strongly connected pond system, Limnol. Oceanogr., 54, 503-511, 2009.

Yallop, M. L., Anesio, M. A., Perkins, R. G., Cook, J., Telling, J., Fagan, D., MacFarlane, J., Stibal, M., Barker, G., Bellas, C., Hodson, A., Tranter, M., Wadham, J., and Roberts, N.: Photophysiology and albedo-changing potential of the ice-algal community on the surface of the Greenland ice sheet, ISME J., 6, 2302-2313, 2012.

Žárský, J. D., Stibal, M., Hodson, A., Sattler, B., Schostag, M., Hansen, L. H., and Psenner, R.: Large cryoconite aggregates on a Svalbard glacier support a diverse microbial community including ammonia-oxidizing archaea, Environ. Res. Lett., 8, 035044, doi:10.1088/1748-9326/8/3/035044, 2013.

Zawierucha, K., Kolicka, M., Takeuchi, N., and Kaczmarek, L.: What animals can live in cryoconite holes? A faunal review, J. Zool., 295, 159-169, 2014. 